\title{
N-myc Oncogene Expression in Porcine Renal Development and Oncogenesis
}

\author{
ISRAEL BENDIT, MARK A. RICH, ROBERT MOLDWIN, PAMELA WABER, \\ BETTIE M. STEINBERG, AND PERRY D. NISEN
}

Department of Pediatrics, University of Texas Southwestern Medical Center, Dallas, Texas 75235-9063

[I.B., P.W., P.D.N.] and Departments of Urology [M.A.R., R.M.], Otolaryngology [B.M.S.], and Pediatrics [I.B., P.W., P.D.N.], Long Island Jewish Medical Center, New Hyde Park, New York 11042

\begin{abstract}
N}$-myc oncogene expression was characterized in porcine kidneys to investigate the potential role of this gene in normal renal development and oncogenesis. $\mathrm{N}$ myc RNA expression was detected in porcine kidneys from birth until 5 wk of age, which corresponds to the time when glomerular differentiation is completed. Immunohistochemical studies revealed that $\mathrm{N}$-myc protein was selectively expressed in the primordia of renal proximal tubule epithelial cells. These cells were cultured in vitro and continued to express $\mathbf{N}-m y c$ for a limited time. Comicroinjection of a mutant ras oncogene and $\mathrm{N}-m y c$ into these cells led to focus formation in soft agar, loss of contact inhibition, and the establishment of an immortalized cell line. These findings support a multistep model of renal oncogenesis that involves overexpression of $\mathrm{N}-m y c$. (Pediatr Res 29: 268-271, 1991)
\end{abstract}

Abbreviations

PCR, polymerase chain reaction DM, defined medium

$\mathrm{N}-m y c$ belongs to a multigene family that includes two other well-defined members: c-myc and L-myc $(1,2)$. Additional related genes have been isolated, but are less well characterized (13). N-myc, c- $m y c$, and L-myc genes have a similar structural organization, share regions of sequence homology (4-6), encode nuclear proteins $(7-10)$, and cooperate with mutant ras to transform rat embryo fibroblast cells in vitro $(5,11-13)$. Transgenic mouse experiments in which $\mathrm{N}-m y c$ was placed under the control of an Ig enhancer caused lymphoid neoplasms $(14,15)$.

$M y c$-family genes are differentially expressed with regard to developmental stage and tissue type. $\mathrm{N}-m y c$ and L-myc expression is restricted, whereas c-myc expression is generalized (1618). N-myc is expressed at highest levels in developing brain and kidney $(16,18-20)$. The stage-specific pattern of $\mathrm{N}-m y c$ expression in developing human kidneys is reflected by the finding of enhanced $\mathrm{N}-m y c$ expression in Wilms' tumor, a neoplasm that arises from primitive renal cells $(18,21)$.

Although the exact functions of $m y c$-family genes are unknown, there is growing evidence that they play critical roles in the cellu!ar commitment to proliferation versus differentiation. In the case of $\mathrm{N}-m y c$, a significant decrease in expression is

Received August 15, 1990: accepted October 18, 1990

Correspondence: Perry Nisen, M.D., Ph.D., Department of Pediatrics, Division of Hematology-Oncology, University of Texas Southwestern Medical Center, 5323 Harry Hines Blvd., Dallas, TX 75235-9063.

P.D.N. was supported by Basil O'Connor Starter Scholar Research Award no. 5-631 from the March of Dimes Birth Defects Foundation. American Cancer Society Award no. CD-407, and a grant from the Elsa U. Pardee Foundation. B.M.S. was supported by NIH Grant SPO1N819214. observed before retinoic acid-induced morphologic differentiation of human neuroblastoma (22). Studies on c-myc are more extensive. Expression of c-myc is activated in a variety of cells as they enter the cell cycle from a quiescent state (23). Similarly, cells can be induced to enter the $\mathrm{S}$ phase by external induction of c- $m y c$ or $\mathrm{N}-m y c$ (24). Down-regulation of $c-m y c$ is associated with terminal differentiation of cells $(25,26)$, whereas constitutive expression of c-myc inhibits differentiation (27, 28). Furthermore, myc proteins contain two structural domains, a leucine zipper (29) and a helix-loop-helix motif (30), that are indicative of transcription and differentiation factors. These observations suggest that combinatorial or differential expression of $m y c$ genes is necessary for progression of cells through particular differentiation pathways (31).

There is extensive evidence that tumorigenesis is a multistep process that may involve the sequential activation of protooncogenes (32-34). Cooperation between oncogenes in different functional categories (for example ras and $m y c$ ) is often necessary for complete transformation of cells $(35-37)$.

We developed a system to investigate the role of $\mathrm{N}-m y c$ gene expression in renal development and oncogenesis. The porcine kidney was chosen because it resembles the human kidney with respect to pattern and time course of differentiation, morphology, and physiology (38). Furthermore, nephroblastoma (termed Wilms' tumor in humans) is a common solid tumor of pigs (38). $\mathrm{N}-m y c$ expression was characterized in porcine kidneys, and cultured porcine renal cells were microinjected with ras and N$m y c$ genes to determine the effects of these oncogenes on renal cell proliferation in vitro.

\section{MATERIALS AND METHODS}

Specimens. Fresh human fetal kidney specimens were obtained from spontaneous abortions as part of a protocol approved by the Human Subjects Investigational Review Board. Fresh, sterile porcine kidneys were salvaged from animals killed by other investigators for unrelated experiments. Specimens were either established in primary cell culture directly or stored in $95 \%$ FCS/ $5 \%$ DMSO at $-70^{\circ} \mathrm{C}$.

Immunochemistry and histochemistry. Five- $\mu \mathrm{m}$ slices of flash frozen tissues were fixed with methanol-acetic acid (3:1) (39). Polyclonal N-myc antibody was obtained from D. Slamon (used at 1:300) (9). Tamm-Horsfall glycoprotein and factor VIII R Ag were detected with specific MAb (Cedar Lane, Ontario, Canada and Dako, Santa Barbara, CA, respectively). Antibodies were detected with a universal immunoperoxidase staining kit (Vector, Burlingame, CA). Cells were counterstained with hematoxylin. Keratin was detected by immunofluorescence using $A E I$ and AE3 antibodies (Hybridtech, San Diego, CA) and fluoresceinlabeled goat anti-mouse IgG (Dako). Alkaline phosphatase and succinic dehydrogenase were detected using standard histochemical methods (40). 
Immunoblotting. Protein from frozen tissues and cultured cells were extracted with NP-40 and phenylmethylsulfonylflouride (41), separated by electrophoresis through a $10 \%$ SDS-polyacrylamide gel, and transferred to nitrocellulose paper (Transblot, BioRad). After blocking residual protein sites with BSA (Promega, Madison, WI), the filter was probed with polyclonal $\mathrm{N}$ $m y c$ antibody (obtained from D. Slamon) (1:300 dilution in Trisbuffered saline pH 7.0, $0.05 \%$ Tween-20) for $16 \mathrm{~h}$ at room temperature. Antibody was detected using an alkaline phosphatase system (Protblot, Promega) using conditions recommended by the manufacturer.

Culture of porcine renal epithelial cells. One-cm sections of outer renal cortex were harvested from fresh, sterile kidneys of newborn and 5-wk-old piglets. Sections of proximal tubule were microdissected using a $20 \times$ dissecting microscope, minced, and filtered through $100-\mu \mathrm{m}$ nylon gauze. Explants were placed in 35-mm Primaria dishes and kept moist with a thin layer of DM for $24 \mathrm{~h}$ at $37^{\circ} \mathrm{C}$ and $5 \% \mathrm{CO}_{2}$. DM was composed of $50 \% \mathrm{~F}-12$ / 50\% Dulbecco's modified Eagle's medium supplemented with porcine regular insulin $(5 \mathrm{U} / \mathrm{mL})$, transferrin $(5 \mu \mathrm{g} / \mathrm{mL})$, selenium $(5 \mu \mathrm{g} / \mathrm{mL})$, triiodothyronine $(4 \mathrm{pg} / \mathrm{mL})$, epidermal growth factor $(50 \mathrm{ng} / \mathrm{mL})$, hydrocortisone $(500 \mathrm{ng} / \mathrm{mL})$, penicillin, and streptomycin. Explant outgrowths were subcultured on LabTek (Nunc, Naperville, IL) chamber slides coated with Matrigel (Collaborative Research, Bedford, MA) in DM. Cells were passaged by washing in PBS followed by incubation at room temperature in a solution of $0.05 \%$ trypsin- $0.02 \%$ EDTA (in Hank's buffered salt solution). Cells that detached in the first 2 min (fibroblasts) were discarded. Cells were subsequently incubated in the same solution at $37^{\circ} \mathrm{C}$ for $5 \mathrm{~min}$ or until cells detached. Detached cells were pelleted, suspended in fresh DM, and plated on LabTek chamber slides (without Matrigel) for subsequent staining and microinjection experiments.

Microinjection and soft-agar selection. T-24 ras (obtained from M. Goldfarb) and N-myc were cloned in eukaryotic expression vectors as described previously (12). Porcine proximal tubule renal epithelial cells were microinjected with DNA at a concentration of $100 \mu \mathrm{g} / \mathrm{mL}\left(1 \times 10^{-9} \mu \mathrm{g} /\right.$ cell $)$ for each construct as described elsewhere (42). After microinjection, cells were cultured undisturbed at $37^{\circ} \mathrm{C}$ for $24 \mathrm{~h}$, trypsinized, and plated in soft agar as described elsewhere (43).

Molecular studies. Chromosomal DNA and total cellular RNA were prepared from frozen tissues as described previously (18, 44). All RNA and DNA blotting and hybridization procedures were performed as described elsewhere $(18,44,45)$. The $\mathrm{N}-m y c$ probe is a $1.8-\mathrm{kb}$ human complementary DNA fragment that contains a part of the 2 nd and all of the 3rd exons of the gene (4).

$P C R$. A sequence of $\mathrm{H}$-ras spanning codon 12 was amplified by PCR using the flanking oligonucleotides $5^{\prime}: 5^{\prime}$ TGACGG AATATAAGCTGGTG3' and $3^{\prime}: 5^{\prime}$ GGGTGCTAGAACGAG GGGCT3'. The reaction mixture contained $1 \mu \mathrm{g}$ of template chromosomal DNA, $0.6 \mu \mathrm{g}$ of each primer, $20 \mathrm{mM}$ of each deoxyribonucleotide triphosphate, and $2.5 \mathrm{U}$ of Taq DNA polymerase (Perkin-Elmer-Cetus, Norwalk, CT) in a total volume of $100 \mu \mathrm{L}$. A Perkin-Elmer-Cetus Thermal Cycler was used at the following settings: denature at $94^{\circ} \mathrm{C}$ for $45 \mathrm{~s}$, reanneal at $55^{\circ} \mathrm{C}$ for $2 \mathrm{~min}$, and extension at $72^{\circ} \mathrm{C}$ for $2 \mathrm{~min}$ for 30 cycles. Amplified DNA was probed with wild-type and T-24 20-mer oligonucleotide probes (GTGGGCGCCGGCGGTGTGGG and GTGGGCGCCGTCGGTGTGGG, respectively).

\section{RESULTS}

$N$-myc oncogene expression in porcine kidney. Previous studies on $\mathrm{N}-m y c$ expression in murine and human kidneys indicated that $\mathrm{N}-m y c$ was overexpressed in fetal kidney, but was undetectable in mature kidney $(16,18,19)$. Gomerular differentiation continues in the porcine kidney for 5 wk after birth. We sought to determine whether $\mathrm{N}-m y c$ expression continued into the new-

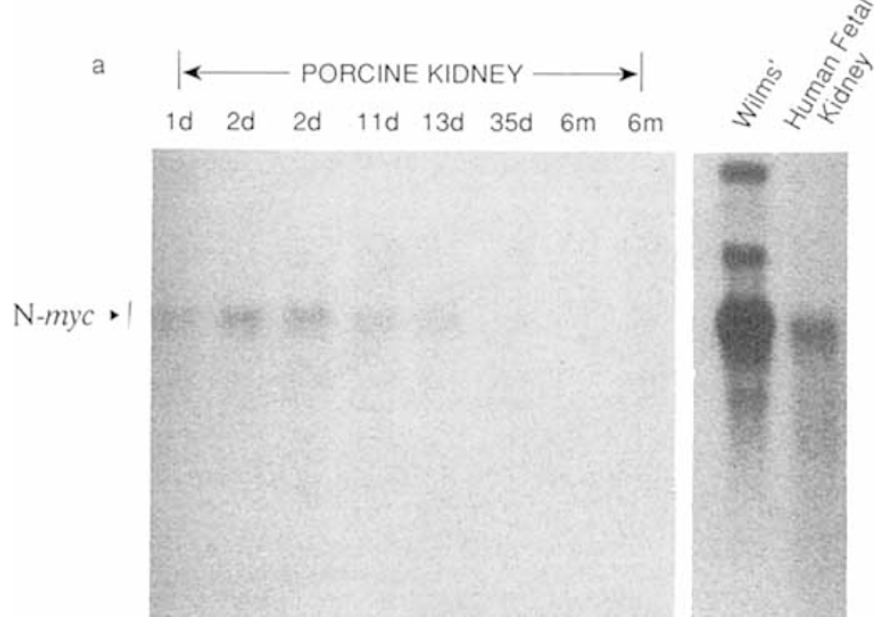

Fig. 1. N-myc RNA expression in porcine kidneys. Ten $\mu \mathrm{g}$ of total cellular RNA extracted from flash frozen porcine kidneys were fractionated by denaturing agarose gel electrophoresis, transferred to a Nitran membrane filter, and hybridized against a [ $\left.{ }^{32} \mathrm{P}\right]$-labeled human $\mathrm{N}-m y c$ cDNA probe. The numbers correspond to the age of the animal when the kidney was obtained. RNA from a primary human Wilms' tumor and human fetal kidney are included for comparison of the relative levels of N-myc expression. Equal amounts of RNA were loaded in each lane. Under the stringent hybridization conditions used, there was no crosshybridization to other $m y c$ family genes. A human c-myc probe detected $\mathrm{a} \sim 2.3$-kb transcript that was expressed at roughly equivalent levels at all time points (data not shown).

born period in pig kidneys corresponding to this postnatal stage of glomerular differentiation. A human cDNA probe was therefore used to detect N-myc RNA transcription by Northern blot analysis of RNA extracted from pig kidneys at different postgestational ages (Fig. 1). N-myc RNA was expressed for 5 wk postnatally, but was not detectable thereafter. The size of the $\mathrm{N}$ myc transcript $(\sim 2.9 \mathrm{~kb})$ is the same in pigs and humans. Porcine lung, heart, liver, and skin were similarly tested for $\mathrm{N}-m y c$ expression. Only newborn brain expressed the gene at levels similar to newborn kidney (data not shown).

Immunohistochemical localization of $N$-myc protein in human fetal and porcine kidneys. Human and porcine kidneys arise embryologically from three different anlage: pronephros, mesonephros, and metanephros. Immunohistochemical means were used to determine the component(s) of the developing kidney that express $\mathrm{N}-m y c$. $\mathrm{N}-m y c$ protein was identified in fetal human kidney and newborn pig kidney, but not in kidney from a 6-moold pig (Fig. 2) or from a 5-y-old child (data not shown). Expression of N-myc protein was restricted to the primordia of proximal tubule epithelial cells indicating that $\mathrm{N}-m y c$ expression is not only tissue-specific and temporally regulated, but also restricted to particular cell lineages. Fetal murine kidneys exhibit a similar pattern of N-myc RNA expression (19). Porcine N-myc protein was detected using monoclonal and polyclonal human $\mathrm{N}-m y c$ antibodies. The ability of human $\mathrm{N}-m y c$ antibodies to detect the corresponding porcine $\mathrm{N}-m y c$ protein was substantiated by immunoblot studies in which human N-myc antibodies detected identical 62- to 64-kD proteins in cell extracts from newborn pig kidney, human fetal kidney, and human neuroblastoma (data not shown)

Culture and characterization of porcine proximal tubule renal epithelial cells. To further characterize $\mathrm{N}-m y c$ expression in porcine kidneys, proximal tubule epithelial cells were cultured in vitro (Fig. $3 a$ ). The cells were identified as proximal tubule by the presence of alkaline phosphatase (Fig. $3 b$ ) and keratin intermediate filaments (data not shown), and the absence of TammHorsfall glycoprotein, factor VIII $\mathrm{R} \mathrm{Ag}$, and succinic dehydrogenase (data not shown). The majority of cells harvested from 
a

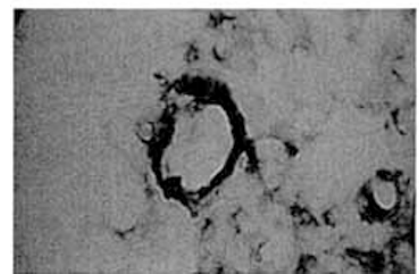

b

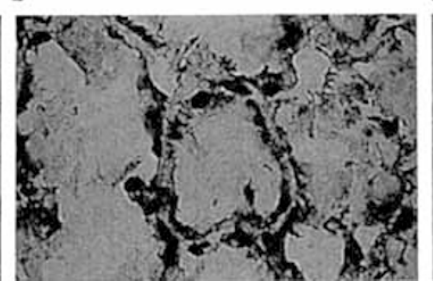

c

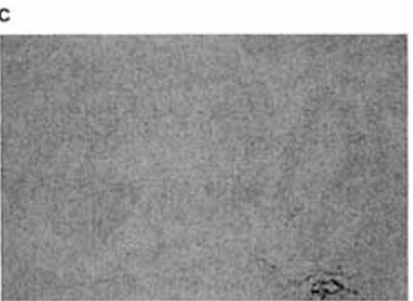

Fig. 2. Immunohistochemical localization of $\mathrm{N}-m y c$ protein in newborn pig and human fetal kidney. N-myc protein was identified by immunoperoxidase staining of flash frozen tissues using a polyclonal anti-human N-myc antibody (see Materials and Methods). A positive reaction in this micrograph is indicated by dark staining. $a$, Human fetal kidney (18 wk gestation); $b$, newborn pig kidney; $c$, pig kidney from a 6-mo-old animal.

a

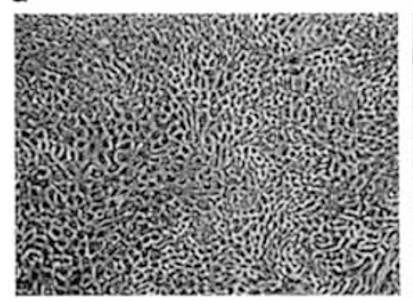

b

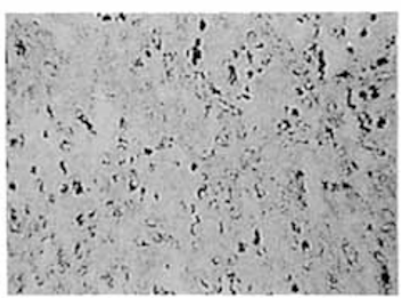

C

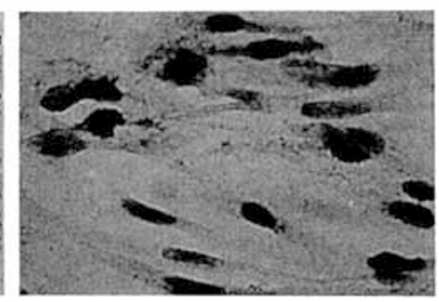

Fig. 3. Characterization of porcine proximal tubule epithelial cells cultured in vitro. Cells were cultured on glass slides as detailed in Materials and Methods. $a$, Hematoxylin and eosin stain of a cell monolayer, magnification $\times 80$. $b$, Histochemical test for alkaline phosphatase. A positive reaction is indicated by black spots. Magnification $\times 80 . c$, Immunohistochemical detection of $\mathrm{N}-m y c$ protein in cultured newborn proximal tubule epithelial cells using anti-human N-myc antibody. Positive nuclear staining is indicated by the dark spots. Magnification $\times 400$.

a

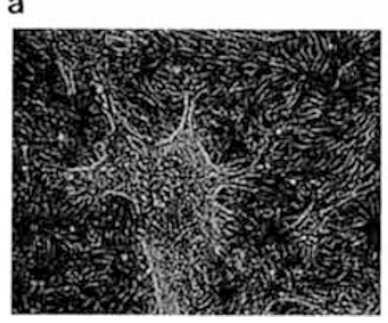

b

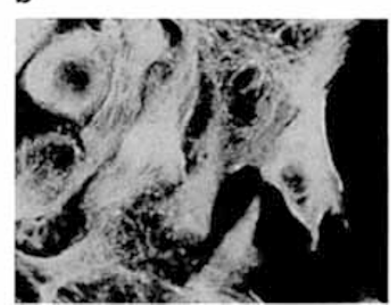

c

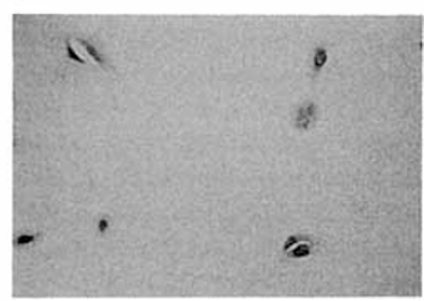

Fig. 4. Characterization of cells microinjected with ras and N-myc. $a$, Phase contrast micrograph of cultured cells depicting loss of contact inhibition. This is in contrast to nontransformed proximal tubule cells (Fig. 3a). Magnification $\times 80$. $b$, Immunofluorescence depicting keratin intermediate filaments. Microinjected cells cultured on a glass slide were treated with keratin antibodies and fluorescein-conjugated second antibody as described in Materials and Methods. Positive immunofluorescence is indicated in white. Magnification $\times 400$. $c$, Immunohistochemical detection of $\mathrm{N}-m y c$ protein. Microinjected cells were treated with $\mathrm{N}-\mathrm{myc}$ antibody as outlined in Figure 3. Positive nuclear staining is indicated by dark spots.

newborn animals expressed $\mathrm{N}-m y c$ protein for $1-2$ wk in primary culture (Fig. $3 c$ ), whereas cells cultured from older animals did not exhibit detectable $\mathrm{N}-m y c$ protein expression (data not shown).

Transformation of porcine proximal renal tubule epithelial cells. Cooperation between "immortalizing" oncogenes such as $\mathrm{N}-m y c$ and "transforming" genes such as ras in the transformation of rat embryo fibroblasts and NIH 3T3 cells has been well characterized (12). The ability of these genes to transform higher eukaryotes, however, has not been well established. Although mutant transforming genes such as ras may be involved in the pathogenesis of pediatric renal tumors, thus far no such genes have been identified. As a first step toward determining if a transforming gene and an immortalizing gene could cooperate to transform porcine proximal tubule cells, expression vectors containing human N-myc and T-24 ras were microinjected separately and together into primary cultures of porcine proximal tubule renal epithelial cells. N-myc was chosen as the immortalizing oncogene because it is endogenously expressed in these cells. Because no bonafide transforming genes have been identified in pediatric renal tumors, T-24 ras was used as an archetypical example of a transforming oncogene. An average of 300 cells were microinjected with each type of DNA construct in three separate experiments. PBS was microinjected as a control. Transformation was measured by the development of foci in soft agar.
A focus was defined as a clump of 10 or more cells in soft agar observed 2 wk after microinjection. The greatest number of foci occurred in cells comicroinjected with $\mathrm{N}-m y c$ and ras. These cells continued to proliferate as cell lines (see below). Microinjection of ras or $\mathrm{N}-\mathrm{myc}$ alone also induced small numbers of foci in soft agar. However, in contrast to cells comicroinjected with $\mathrm{N}-m y c$ and ras, cells microinjected with $\mathrm{N}-m y c$ or ras alone did not replicate after being taken out of soft agar. These cells were therefore either clumps of nontransformed cells or abortive transformation events.

Transformed cells that arose by comicroinjection with ras and $\mathrm{N}-m y c$ continue to grow in defined media after more than 60 passages. In contrast to nontransformed renal epithelial cells (Fig. 3a), transformed cells have lost contact inhibition (Fig. 4a). The transformed cells continue to exhibit epithelial features as manifested by the presence of keratin intermediate filaments (Fig. 4b). Although nontransformed newborn proximal tubule cells no longer express $\mathrm{N}-m y c$ after $1-2$ wk in culture, transformed cells after 60 passages continue to overexpress $\mathrm{N}$-myc RNA and protein as evidenced by Northern blot hybridization and immunoblot analysis, respectively (data not shown). PCR was used to show that the T-24 ras oncogene originally introduced by microinjection was still present in the transformed cells (data not shown). 


\section{DISCUSSION}

N-myc RNA expression was observed in porcine kidneys for 5 wk postnatally, after which time it was no longer detectable. This time frame coincides with the period when postnatal glomerular differentiation continues in the pig and is consistent with the hypothesis that $\mathrm{N}-m y c$ expression occurs in proliferating cells that are not yet fully differentiated.

$\mathrm{N}-m y c$ protein expression was localized to the primordia of proximal tubules of human fetal kidneys and porcine newborn kidneys. These findings are compatible with the observations of Hirvonen et al. (20), who used in situ hybridization to show that $\mathrm{N}-m y c$ was selectively expressed in differentiating epithelial mesenchyme in 16- to 19-wk human fetal kidneys, and the studies of Mugrauer et al. (19) in fetal mice. N-myc expression in development is therefore not only temporally and tissue-restricted, but also cell lineage-specific within an organ.

Our ability to transform primary cultures of porcine renal cells with $\mathrm{N}-m y c$ and ras is consistent with a multistep model of renal oncogenesis that involves overexpression of N-myc. Although there is no evidence that ras is activated in pediatric renal tumors, it is possible that a mutation could activate an oncogene similar to ras in a fetal or newborn renal cell that normally expresses $\mathrm{N}$ $m y c$. A second event that results in aberrant overexpression of $\mathrm{N}-m y c$ (either a dominant mutation that activates $\mathrm{N}-m y c$ or loss of heterozygosity for a putative suppressor gene that normally functions to suppress $\mathrm{N}-m y c$ ) would lead to renal transformation It is therefore conceivable that in addition to its potential function in renal development $\mathrm{N}-m y c$ also plays a role in the pathogenesis of pediatric renal neoplasia (18).

\section{REFERENCES}

1. Alt F, DePinho R, Zimmerman K, Legouy E, Hatton K, Ferrier P, Tesfaye A Yancopoulos GD, Nisen PD 1986 The human myc-gene family. Cold Spring Harbor Symp Quant Biol 51:931-941

2. DePinho R, Mitsock L, Hatton K, Ferrier P, Zimmerman K, Legouy E Tesfaye A, Collum R, Yancopoulos GD, Nisen PD, Kriz R, Alt F 1987 The MYC-family of cellular oncogenes. J Cell Biochem 33:257-260

3. Ingvarsson S, Asker C, Axelson H, Klein G, Sumegi J 1988 Structure and expression of B-myc, a new member of the myc gene family. Mol Cell Bio 8:3168-3174

4. Kohl N, Legouy E, DePinho R, Nisen PD, Smith R, Gee C, Alt FW 1986 Human N-myc gene is closely related in organization and sequence to $\mathrm{c}$ myc. Nature 319:73-77

5. DePinho R, Legouy E, Feldman L, Kohl N, Yancopoulos GD, Alt FW 1986 Structure and expression of the murine N-myc gene. Proc Natl Acad Sci USA 83:1827-1831

6. Legouy E, DePinho R, Zimmerman K, Collum R, Yancopoulos G, Mitsock L, Kriz R, Alt F 1987 Structure and expression of the murine L-myc gene. EMBO J 6:3359-3366

7. Persson H, Leder P 1984 Nuclear localization and binding properties of a protein expressed by the c-myc oncogene. Science 225:718-720

8. Ikegaki N, Bukovsky J, Kennett R 1986 Identification and characterization of the NMYC gene product in human neuroblastoma cells by monoclonal antibodies with defined specificities. Proc Natl Acad Sci USA 83:5929-5933

9. Slamon D, Boone T, Seeger R, Keith D, Chazin V, Lee H, Souza L 1986 Identification and characterization of the protein encoded by the human $\mathrm{N}$ myc oncogene. Science 232:768-772

10. Kaye F, Battey J, Nau M, Brooks B, Seifter E, DeGreve J, Birrer M, Sausville $E$, Minna J 1988 Structure and expression of the human L-myc gene reveal a complex pattern of alternative mRNA processing. Mol Cell Biol 8:186195

11. Schwab M, Varmus HE, Bishop JM 1985 Human N-myc gene contributes to neoplastic transformation of mammalian cells in culture. Nature 316:160162

12. Yancopoulos GD, Nisen PD, Tesfaye A, Kohl N, Goldfarb M, Alt F $1985 \mathrm{~N}$ myc can cooperate with ras to transform normal cells in culture. Proc Nat Acad Sci USA 82:5455-5459

13. Birrer M, Segal S, DeGreve J, Kaye F, Sausville E, Minna J 1987 L-myc cooperates with ras to transform primary rat embryo fibroblasts. Mol Cell Biol 8:2668-2373

14. Dildrop R, Ma A, Zimmerman K, Hsu E, Tesfaye A, DePinho R, Alt FW $1989 \mathrm{IgH}$ enhancer-mediated deregulation of $\mathrm{N}$-myc gene expression in transgenic mice: generation of lymphoid neoplasms that lack c-myc expression. EMBO J 8:1121-1128

15. Rosenbaum H, Webb E, Adams JM, Cory S, Harris AW $1989 \mathrm{~N}-m y c$ transgene promotes B lymphoid proliferation, elicits lymphomas and reveals crossregulation with c-myc. EMBO J 8:749-755

16. Zimmerman $K$, Yancopoulos $G$, Collum $R$, Smith $R$, Kohl N, Denis K. Nau M, Witte O, Toran-Allerand D, Gee C, Minna J, Alt F 1986 Differential expression of myc family genes during murine development. Nature 319:780-783

17. Jakobovits A, Schwab M, Bishop JM, Martin G 1985 Expression of N-myc in teratocarcinoma stem cells and mouse embryos. Nature 318:188-191

18. Nisen PD, Zimmerman K, Cotter S, Gilbert F, Alt F 1986 Enhanced expression of the N-myc gene in Wilms' tumors. Cancer Res 46:6217-6222

19. Mugrauer $G$, Alt F, Ekblom F $1988 \mathrm{~N}$-myc proto-oncogene during organogenesis in the developing mouse as revealed by in situ hybridization. J Cell Biol 107:1325-1335

20. Hirvonen $\mathrm{H}$, Sandberg $\mathrm{M}$, Kalimo $\mathrm{H}$, Hukkanen V, Vuorio E, Salmi TT, Alitalo K 1989 The N-myc proto-oncogene and IGF-Il growth factor mRNAs are expressed by distinct cells in human fetal kidney and brain. J Cell Biol 108:1093-1104

21. Shaw A, Poirier V, Tyler S, Mott M, Berry J, Maitland N 1988 Expression of the $\mathrm{N}$-myc oncogene in Wilms' tumour and related tissues. Oncogene 3:143149

22. Thiele C, Reynolds CP, Israel MA 1985 Decreased expression of N-myc precedes retinoic acid-induced morphological differentiation of human neuroblastoma. Nature 313:464-466

23. Kelly K, Cochran B, Styles C, Leder P 1984 Cell specific regulation of the cmyc gene by lymphocyte mitogens and platelet-derived growth factor. Cell 35:603-610

24. Cavalieri F, Goldfarb M 1987 Growth factor deprived BALB/c 3T3 murine fibroblasts can enter the $S$ phase after induction of c-myc gene expression. Mol Cell Biol 7:3554-3560

25. Holt J, Redner R, Nienhuis A 1988 An oligomer complementary to c-myc mRNA inhibits proliferation of HL-60 promyelocytic cells and induces differentiation. Mol Cell Biol 8:963-973

26. Prochownik E, Kukowska J, Rodgers C 1988 c-myc antisense transcripts accelerate differentiation and inhibit Gl progression in murine erythroleukemia cells. Mol Cell Biol 8:3683-3695

27. Coppola J, Parker J, Schuler G, Cole M 1989 Continued withdrawal from the cell cycle and regulation of cellular genes in mouse erythroleukemia cells blocked in differentiation by the c-myc oncogene. Mol Cell Biol 9:17141720

28. Freytag S 1988 Enforced expression of the c-myc oncogene inhibits cell differentiation by precluding entry into a distinct predifferentiation state in G0/G1. Mol Cell Biol 8:1614-1624

29. Landschulz W, Johnson P, McKnight S 1988 The leucine zipper: a hypothetical structure common to a new class of DNA binding proteins. Science 240:1759-1764

30. Murre C, Schonleber-McCaw P. Baltimore D 1989 A new DNA binding and dimerization motif in immunoglobulin enhancer binding, daughterless, myo D, and myc proteins. Cell 56:777-783

31. Collum RG, Alt FW 1990 Are myc proteins transcription factors? Cancer Cells 2:69-75

32. Bishop JM 1987 The molecular genetics of cancer. Science 235:305-310

33. Barbacid M 1987 Ras genes. Annu Rev Biochem 56:779-827

34. Weinberg RA 1985 The action of oncogenes in the cytoplasm and nucleus. Science 230:770-776

35. Land H, Parada L, Weinberg RA 1983 Tumorigenic conversion of primary embryo fibroblasts requires at least two cooperating oncogenes. Nature 304:596-602

36. Ruley HE 1983 Adenovirus early region IA enables viral and cellular transforming genes to transform primary cells in culture. Nature 304:602-606

37. Thompson TC, Southgate J, Kitchener G, Land H 1989 Multistage carcinogenesis induced by ras and myc oncogenes in a reconstituted organ. Cell 56:917-930

38. Tumbleson ME 1986 Swine in Biomedical Research Alan R Liss, New York

39. Mukai K, Rosai J 1980 Immunoperoxidase techniques in pathology. In: Fenoglio C, Wolff M (eds) Progress in Surgical Pathology. Masson, New York, pp 15-49

40. Luna L 1968 Manual of Histologic Staining of the Armed Forces Institute of Pathology. McGraw-Hill, New York

41. Yang SY 1989 A standard method for detection of HLA-A and HLA-B alleles by one dimensional isoelectric focusing gel electrophoresis. In: Immunology of HLA. Springer-Verlag, New York, pp 332-335

42. Graesseman M, Graesseman A 1983 Microinjection of tissue culture cells. In: Wu R (ed) Methods in Enzymology. Academic Press, New York, pp 482493

43. Freshney R 1983 Culture of Animal Cells. Alan R. Liss, New York

44. Nisen PD, Waber P, Rich M, Pierce S, Garvin J, Gilbert F, Lanzkowsky P $1988 \mathrm{~N}$-myc oncogene RNA expression in neuroblastoma. J Natl Cancer Inst 80:1633-1637

45. Kohl N, Gee C. Alt FW 1984 Activated expression of the N-myc gene in human neuroblastomas and related tumors. Science 226:1335-1337 